\title{
Microbiology of a northern river: bacterial distribution and relationship to suspended sediment and organic carbon
}

\author{
G. G. Geesey ${ }^{1}$ and J. W. Costerton \\ Department of Biology, University of Calgary, Calgary, Alta., Canada \\ Accepted June 7. 1979
}

Geesty, G. G., and J. W. Costerton. 1979. Microbiology of a northern river: bacterial distribution and relationship to suspended sediment and organic carbon. Can. J. Microbiol. 25: $1058-1062$.

Epifluorescent microscopy showed as many as $4 \times 10^{6}$ bacteria/mL in the turbid waters of the Athabasca River near the tal sand deposits in northeastern Alberta. The numbers were usually similar upstream and downstream $(60 \mathrm{~km})$ from pilot-mining operations. The majority of bacteria existed as free-living cells in spite of the fact there were high concentrations of suspended sediment present (average $220 \mathrm{mg} / \mathrm{L}$ ) during the ice-free period. Fluctuations in bacterial concentration were positively correlated $(r=0.86, P<0.05)$ with total organic carbon concentrations in the river water.

GEESEY, G. G., el J. W. COSTERTON. 1979. Microbiology of a northern river: bacterial distribution and relationship to suspended sediment and organic carbon. Can. J. Microbiol. 25: $1058-1062$.

La microscopie en épifluorescence a révélé une présence de bactéries aussi élevée que $4 \times$ $10^{6} / \mathrm{mL}$ dans les eaux troubles de la rivière Athabasca près des dépôts de sables bitumineux du nord-est de l'Alberta. Que ce soit en amont ou en aval $(60 \mathrm{~km})$ du champ d'opération pilote. les comptes bactériens ont été habituellement semblables. Les bactéries existent, en majorité, à létat habituellement semblables. Les bactéries existent, en majorité. à l"état libre en dépit de la présence de concentrations élevées de sédiments en suspension (environ $220 \mathrm{mg} / \mathrm{L}$ ) durant la periode sans glace. Les fluctuations en concentrations bactériennes présentent une corrélation positive $(r=0.86 . P<0.05)$ avec les concentrations en carbone organique total de l'eau de la rivière.

[Traduit par le journal]

\section{Introduction}

The microbiology of flowing waters is not well understood and virtually nothing is known of the microbial populations of northern rivers of North America. The land drained by these rivers is, however, undergoing rapid change. Future development in areas such as the Athabasca Tar Sands of northeastern Alberta could affect the water quality of the drainage systems. We therefore initiated a study to determine concentrations of bacteria, their distribution, and their relation to suspended sediment and organic carbon concentration in the Athabasca River. Since bacteria are known to respond to changes in their environment (i.e., chemical, thermal, and particulate loading) (Deufel 1972; Hood et al. 1975; Stlotzky 1965), close surveillance of this ubiquitous biological component may provide a sensitive indicator of water quality. This investigation was initiated at a time during which only pilot-mining operations were in progress, so that the results may be used as baseline data for future assessment of water quality following expanded mining operations.

${ }^{1}$ Author to whom reprint requests should be addressed. Present address: Department of Microbiology. California State University, Long Beach, California 90840.

\section{Materials and Methods}

Study Areed

Sampling locations were established on the Athabasca River between Fort McMurray, Alberta $\left(56^{\circ} 44^{\prime} \mathrm{N}, 111^{\circ} 23^{\prime} \mathrm{E}\right)$ and the Chipewyan Indian Reservation $\left(57^{\circ} 54^{\prime} \mathrm{N}, 111^{\circ} 24^{\prime} \mathrm{E}\right.$ ) (Fig. 1). Three sites $(2,3$, and 4 ) were located upstream from an operative tar sands mining plant. two sites ( 5 and $5 a$ ) were located directly adjacent to the tar sands plant, and five sites $(6,7,8,9$, and 10$)$ were located downstream from the plant and mining operation (Fig. 1).

\section{Sampling Procedere}

A single water sample was collected at each sampling site for both scanning electron microscopy (SEM) and epifluorescence microscopy (EPM) in sterile glass bottles using a bacteriological water sampler (No. 003WA 100, Kahl Scientific Corp.). An additional water sample was collected at each site in polyethylene bottles for total organic carbon (TOC), suspended sediment, and turbidity determinations.

\section{Scanning Electron Microscopy}

One to $5-\mathrm{mL}$ subsamples were filtered through $2,4-\mathrm{cm}^{-}$ diameter Nuclepore membranes $(0.2 \mu \mathrm{m}$ pore size $)$ and the particulate material that was retained was fixed by immersing the entire membrane in a sterile vial containing $0.5 \%$ glutaraldehyde in $0.067 M$ cacodylate buffer, $\mathrm{pH} 8.0$, which had been equilibrated to river temperature. Upon returning to the laboratory, the membranes and their contents were postfixed in $2 \%$ osmium tetroxide and dehydrated in ethanol prior to drying by the critical point method (Cohen et al. 1968). The membranes were mounted on aluminum "stubs," coated with gold, and examined in a Cambridge stereoscan electron microscope. 


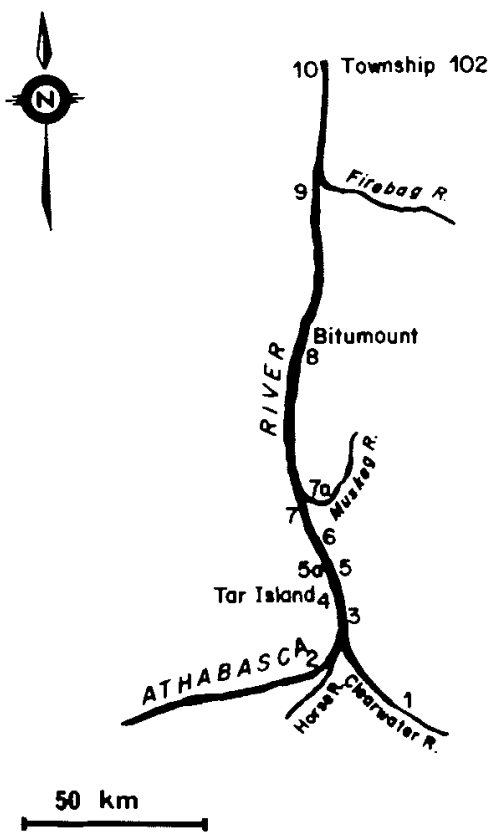

Fig. I. Study area: Athabasca River. Present and proposed Tar Sands mining operations are located between sites 4 and 6 .

Epifluorescence Microscopy

Two subsamples were filtered as above and transferred to plastic petri dishes containing a glutaraldehyde atmosphere (Geesey et al. 1978). The volume of water that was filtered was adjusted so that there were from 10 to 100 bacteria per microscope field. Upon returning to the laboratory, the glutaraldehyde-fixed cells were prepared for EPM by the method of Zimmermann and Meyer-Reil (1974). Briefly, the cells on the membrane were stained with acridine orange ( $100 \mathrm{mg} / \mathrm{L} 0.1 \mathrm{M}$ potassium phosphate buffer, $\mathrm{pH} 7.5$ ) for several minutes. The membrane was destained with isopropyl al cohol for $30 \mathrm{~s}$, air-dried, mounted on a glass slide containing a drop of non-fluorescing immersion oil, and overlayed with a glass coverslip. The bacteria on the membrane were observed under a Zeiss standard 16 microscope (mag. 1000x) equipped with epifluorescence and illuminated with an $\mathrm{HBO} 50-\mathrm{W}$ mercury arc burner (filter combination: excitation:KP 490. LP 455; beam splitter:LP 510; batrier filter:LP 520). Bacterial concentrations in the flowing water were extrapolated from the mean number of fluorescing orange and green cells observed in 10 different grid areas $\left(0.0025 \mathrm{~mm}^{2}\right)$ on each membrane (two per site).

Sraristical Analyses

Bacterial counts were subjected to a $t$-distribution test (Bishop 1971) to determine whether significant differences existed between bacterial concentrations upstream and downstream from the tar sands mining operations. One-way analysis of variance (Elliott 1971) was used to test for significant differences in bacterial concentrations in surface waters and at various depths in the water column at each site. One-way analysis of variance was also used to test for significant seasonal differences in bacterial concentrations.

Samples for TOC determinations were kept cool and in the dark and analyzed within $48 \mathrm{~h}$ of collection using a Beckman $915 \mathrm{~B}$ dual channel carbon analyzer (Naquadat $06001 \mathrm{~L}$ ). Sus- pended sediments were determined by weighing the residue on Whatman GF/C glass fiber filters after drying at $110^{\circ} \mathrm{C}$ for $1 \mathrm{~h}$ (Naquadat $02073 \mathrm{~L}$ ), and turbidity was measured by photometry using a Hach turbidimeter (Naquadat 10401 L). Samples were collected monthly except during the period of ice formation in November:

\section{Results}

\section{Bacterial Distribution}

Bacterial concentrations determined at 10 locations extending upstream and downstream from the tar sands mining operations were within 1 order of magnitude during any one sampling period (Fig. 2). The coefficient of variation among bacterial counts obtained at the various sampling locations ranged from 16 to 69 depending upon the sampling period. The standard error among replicate counts (two per site) ranged from 43 to $75 \%$ of the mean. No significant differences $(P<0.05)$ were observed among bacterial counts obtained from samples from horizontal $(n=27, F<1)$ and vertical $(n=27$, $F=0.28$ ) profiles at each location based on oneway analysis of variance. Bacterial concentrations did show significant variations ( $n=75, F=60.2$ ) on a seasonal basis. The highest concentrations $(2 \times$ $10^{6}$ cells $/ \mathrm{mL}$ ) occurred in the spring and fall while the lowest $\left(1 \times 10^{5}\right.$ cells $\left./ \mathrm{mL}\right)$ occurred during a period of record rainfall in late August (Fig. 2).

\section{Particulate Matter}

The Athabasca, like many northern rivers, is very turbid and carries suspended sediment loads

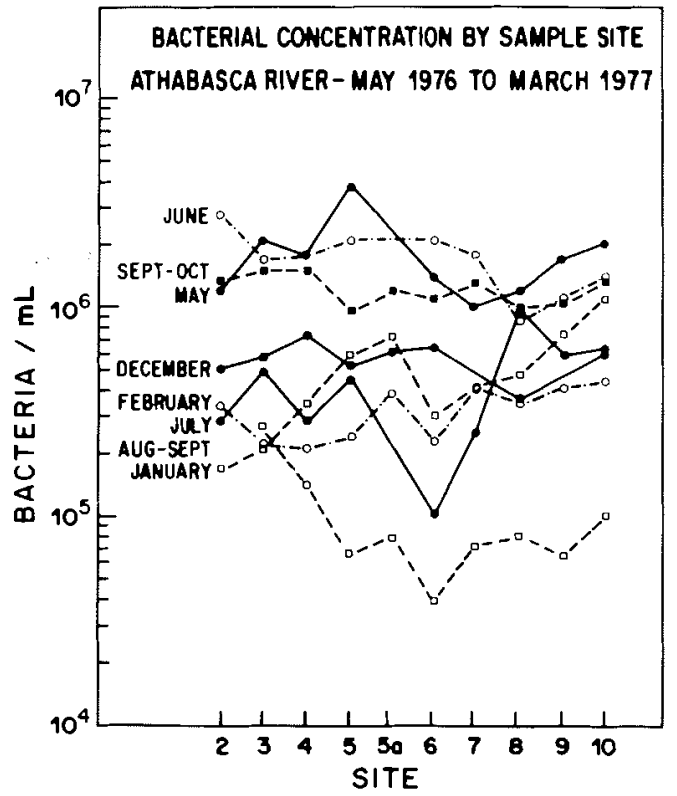

Fig. 2. Bacterial concentrations in the Athabasca River from May 1976 to February 1977. 


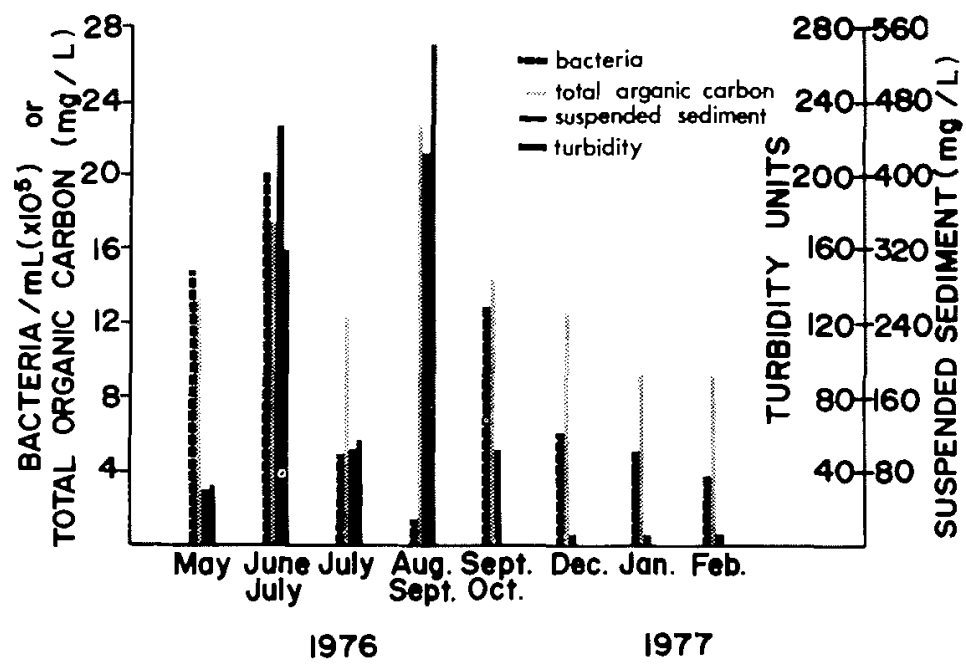

Fici. 3. Seasonal bacterial concentrations, total organic carbon, suspended sediment and turbidity in the Athabasca River. Values represent the mean obtained from the 10 simpling sites.

of as high as $560 \mathrm{mg} / \mathrm{L}$ during spring runoff following rainstorms (Fig. 3). While high concentrations of bacteria were recovered from these waters, the bulk of the suspended material was composed of silt particles which ranged from 5 to $50 \mu \mathrm{m}$ in size (Fig. $4 a, b$, and $c$ ). No close correlation was obtained, however, between bacterial concentration and suspended sediment $(r=-0.49)$ or turbidity $(r$ $=0.21$ ) over the 10 -month period, except that all were low during the winter months (Fig. 3).

An extensive survey by EPM revealed that the majority $(76 \%)$ of the bacteria were free-living cells. The remainder $(24 \%)$ were associated with the surfaces of diatoms and amorphous material (Fig. 4e and $f$ ). The adherent bacteria, in most cases, were concentrated in the crevices of the detrital material (Fig. 4d), while the more exposed planar surfaces of silt particles were conspicuously devoid of bacteria (Fig. $4 a$ and $b$ ). The majority of the bacteria in the river were coccoidal or rodshaped. Cell volumes were estimated from size measurements obtained from scanning electron micrographs and ranged from 0.05 to $1.5 \mu \mathrm{m}^{3}$ with a mean cell volume of $0.2 \mu \mathrm{m}^{3}$. The small size of many bacteria made it difficult to estimate cell volumes based on EPM (Fig. 4f). Fungal mycelia were observed very infrequently in either SEM or EPM preparations.

\section{Total Organic Carbon}

Seasonal fluctuations in bacterial concentrations generally coincided with fluctuations in TOC (Fig. 3 ). An exception was noted in the summer during which time there was an increase in the bacteria:TOC ratio. This was particularly evident in the August-September sampling period im- mediately following a period of record high rainfall in the area. At this time, the mean bacterial concentration dropped to its lowest level while TOC attained the highest mean concentration observed during the 10-month study. Fluctuations in bacterial concentrations correlated well with TOC concentrations $(r=0.86, P<0.05)$ when data from the August-September sampling period were excluded. There was good correlation between bacterial concentration (Fig. 2) and TOC (Fig. 5) during the August-September period when these parameters were compared on a site-to-site basis $(r$ $=0.97, P<0.05$ ).

\section{Discussion}

The data demonstrated that total bacterial concentrations did not differ appreciably in surface waters or throughout the water column in the Athabasca River. Comparisons of bacterial concentrations in samples collected upstream and downstream from the tar sands indicated that the present small-scale mining operations were not threatening water quality at the present time. Data from physical and chemical measurements at the same locations (not shown) also supported this conclusion.

In contrast to the findings of Jannasch (1956), in which $99 \%$ of the microbial population in the turbid waters of the Nile River was attached to silt particles, the majority of bacteria in the silt-laden Athabasca River existed as free-floating cells. The Athabasca, however, is a fast-moving river so that bacterial development on the exposed planar surfaces of the suspended silt particles would be less likely to occur due to greater surface abrasion generated by the increased frequency of particle colli- 

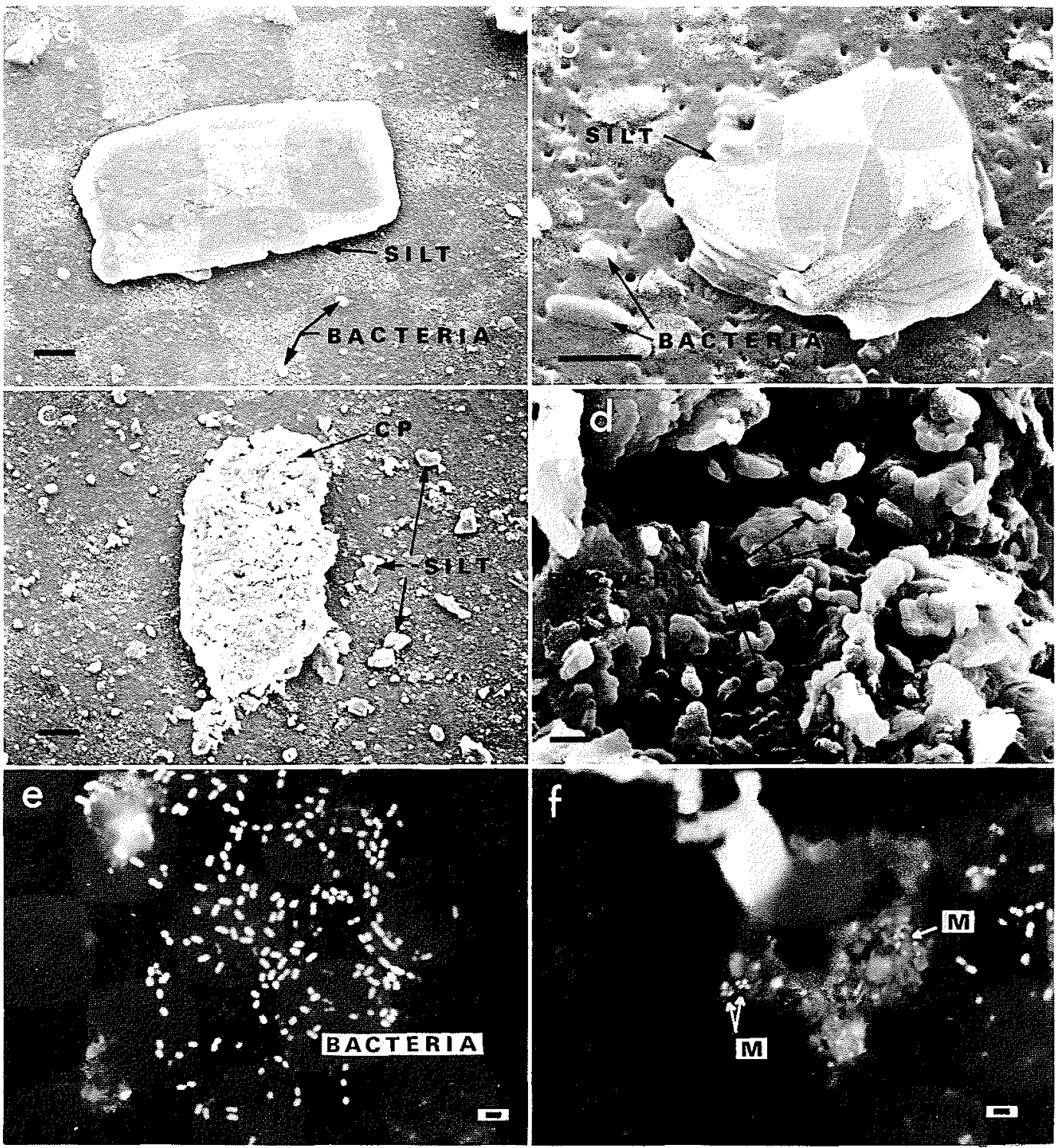

FiG. 4. Microscopic view of particulate material recovered from Athabasca River water. Fig. $4(a)$ through $(d)$ are scanning electron micrographs of the suspended material. Note the absence of bacteria on the exposed planar surfaces of the silt particles in $(a)$ and $(b)$. Fig. $4(d)$ is an enlarged area of $(c)$ revealing the small "bacteria-like" objects concentrated in the crevices of this cavitated particle (CP). Fig. $4\left(o^{\circ}\right)$ and $(f)$ are epiftuorescent micrographs of suspended particulate material. Note the large numbers of free-living bacteria (white) in $(e)$ and the microcolonies (M) of bacteria associated with poorly stained amorphous material in $(f)$. Bars represent $10,3,30$, and $l \mu \mathrm{m}$ in $(e)$ and $(f)$.

sions. Epifluoresence microscopy showed that small fluorescing cocci were concentrated on the surfaces of certain suspended particles. These small cells likely corresponded to the short rodshaped objects seen by SEM in the more protected crevices of less numerous cavitated particles.

The apparent relationship between bacterial and TOC concentrations suggests that increased bacterial numbers will result from surface disturbance or from spillover or leakage from processing plants or tailing ponds or from percolation into underground aquifers (Maugh 1978)

As shown in this study, seasonal or episodic events can greatly influence the organic load in the river and hence, could easily obscure any effects directly attributable to tar sands mining activities. Thus, in order to apply a microbiological approach to the determination of tar sands related organic pollution, it would be desirable to identify specific physiological groups of bacteria in the river which 


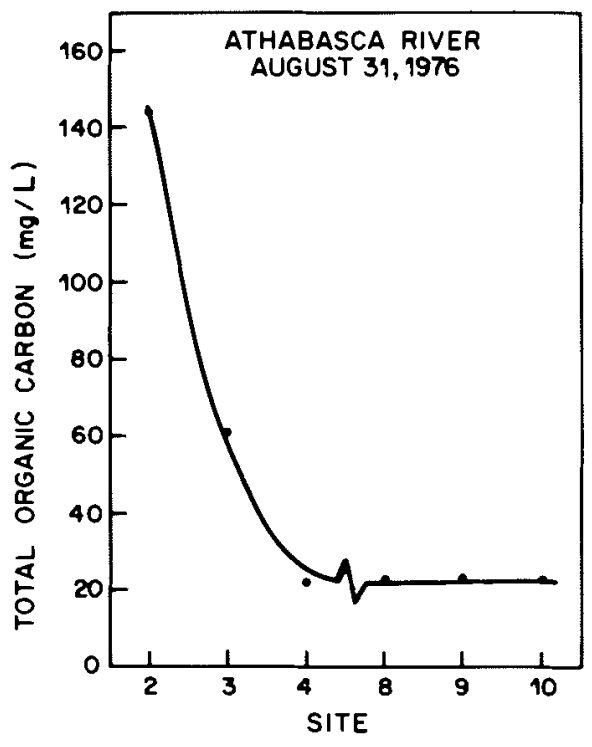

Fig. 5. Site-to-site total organic carbon concentrations in the Athabasca River immediately following a period of record-high rainfall in the area.

selectively respond to constituents of the bitumen or synthetic crude oil. Efforts are currently being directed to the determination of in situ activities of hydrocarbon-utilizing bacteria in the river.

\section{Acknowledgement}

Special thanks are issued to Liz Middlemiss. Judy Genaske, and Dale Cooper for their microscopy work. This study was supported by the Al- berta Oil Sands Environmental Research Program (AOSERP) and chemical and physical data were provided by Chemex Labs (Alberta) Ltd., 2021 41 Ave. N.E., Calgary, Alberta.

Bishop. O. N. 1971. Statistics for biology. 2nd ed. Longman Group Ltd, , London, G.B.

Cohen, A. L., D. P. Marlow, and G. E. Garner. 1968, A rapid critical point method using fluorocarbons (Freons) as intermediate and transition fluids. J. Microsc. (Paris), 7: $331-342$.

DEUFEL, L. 1972. Direct counts and plate counts of bacteria in the Danube between Breg Spring and Ulm. Arch. Hydrobiol. Suppl. 44: 1-9.

ElLiotT, J. M. 1971. Some methods for the statistical analysis of samples of benthic invertebrates. Sci Publ. No. 25. Freshwater Biol. Assoc., Ambleside, G.B.

Geesey, G. G., R. Mutch, J. W. Costerton, and R. B. GrEen. 1978. Sessile bacteria: an important conponent of the microbial population in small mountain streams. Limnol. Oceanogr, 23: 1214-1223.

HOOD, M. A.. W. S. Bishop. F. W. Bishop, S. P. MEYERS, and T. WHELAN. 1975. Microbial indicators of oil-rich salt marsh sediments. Appl. Microbiol. 30: 982-987.

JANNASCH. H. W. 1956. Vergleichende Bakteriologische Untersuchung der Adsorptionswirkung des Nil-Treibschlammes. Ber. Limnol. Flussst. Freudenthal Munden. 7: 21-27.

MaUGH, T. H. 1978. Tar sands: a new fuels industry takes shape. Science, 199: 756-760.

STLOTZKY, G. 1965. Influence of clay minerals on microorganisms II. Effects of various clay species, homoionic clays, and other particles on bacteria. Can. J. Microbiol. 12: 831-848.

ZimmermanN, R., and L. Meyer-ReIL. 1974. A new method for fluorescence staining of bacterial populations on membrane filters. Kiel Meeresforsch. 30: 24-27. 